\title{
NATIONAL IDENTITY VERSUS SOCIAL COHESION: AN ADVOCACY FOR ENGLISH LANGUAGE
}

\author{
Juliana Chinwe, Njoku \\ \& \\ Chika Queen Udeh \\ Alvan Ikoku College of Education, Owerri, Nigeria \\ *http://dx.doi.org/10.4314/ujah.v14i3.6
}

\begin{abstract}
When it comes to matters of National Identity, the clamour usually is for the promotion of indigenous languages. However, English Language has bequeathed enough legacies to Nigeria that cannot be easily wished away. This paper therefore seeks to explicate how English language can be used to solve the problems of ethnicity, social disorder and the recurring state of insecurity in Nigeria. Generally, language is essentially used for communication and interaction. People interact in order to receive or give information and to accomplish tasks. Hence, language is a means of social control. It is through communication that collaboration and co-operation occur. Conflict arises only when there is a breakdown in the communication channel. This is usually the problem in a multi-lingual society. Nigeria being a multi-lingual and multi-ethnic society, needs a common language which majority of the citizens can understand so as to enhance communication amongst the diverse groups that make up the polity. This paper advocates the use of English language in every section of the polity. This is very important because English Language is neutral and does not engender any ethnic hostility. It rather bridges the communication gap amongst a people with diverse tongues. When there is communication gap, strained relationships and conflicts occur, usually degenerating into violence and break-down of law and order. In the face of the myriads of problems that Nigeria is experiencing, this paper strongly submits that the use of English language in every sector of the polity would certainly elicit co-operation and friendliness and ensure social stability.
\end{abstract}




\section{Introduction}

National Identity refers to the characteristics that make a nation distinct from other nations. People usually clamour for the promotion of indigenous languages when it comes to matters of national identity. Indigenous languages are seen as the indices of a people's identity. They are regarded as the platform for expressing a people's culture, beliefs and traditional values. Those who advocate the promotion of indigenous languages, as a means of preserving our national identity, do so on the premise that they would help promote national unity and develop 'a single national consciousness'. The reality on ground indicates that the ethno-linguistic configuration of Nigeria hinders the realization of this lofty ideal.

Nigeria has over 400 indigenous languages and not less than 250 ethnic groups. These ethnic groups are best described as 'units of nation within the nation state'. They have their different cultures, different religions and different languages. What obtain in Nigeria's nation state is ethnic attachment, ethnic loyalty and solidarity that over-rides collective national interests. These ethnic groups never considered themselves as descents from the same ancestry. Hence, there is no feeling of national unity amongst them. There is hostility and unhealthy rivalry among the different ethnic groups. Often, an ethnic clash in one part of the country sets off a chain of reprisal riots and attack in other parts of the country. Innocent citizens are killed and properties worth billions of naira are destroyed on the slightest provocation. 
Inter-twined with ethnicity is the language problem. In a multilingual situation, it is easy to misunderstand or misinterpret what the other has said. This communication gap breeds suspicion and hostility, which usually degenerate into violence and break-down of law and order.

There is no unity in the country and there is no sense of oneness (that is, the sense of belonging to one nation state). Even in the cities, people tend to congregate along ethnolinguistic lines. Ethnicity is a strong factor in the choice of where to live. This kind of attitude prepares ground for further conflicts, violent confrontations and social disorder. Cases in point are the clashes between the OPC (a militia group from the Yoruba ethnic group) and the Hausas that led to the death of a nearly hundred people in Lagos (Buhaya, online news); the reprisal riots that took place in Aba in retaliation to the killing of the Igbos in the North, and the insurgence in the North in the garb of Boko Haram.

From the foregoing, we can see that the problems are complex, problems emanating from ethnicity and multilingualism. It is therefore imperative to strive for social cohesion, that is, peaceful co-existence amongst the various ethnic nationals that make up the polity. This can only be achieved through developing a linguistic network that will facilitate social cohesion, national integration and unity. This is where English Language comes in.

This paper advocates the use of English Language in every section of the polity. English Language does not have any ethnic affiliation in Nigeria and as such does not provoke any ethnic hostility. It bridges the gap in communication among 
the various ethno-linguistic groups that make up the Nigerian nation.

It is on this backdrop that the paper examines the notion of national identity, ex-rays the ethno-linguistic configuration of Nigeria with its attendant problems; and weighs in balance the two sides of the argument - the need for social cohesion and the quest for national identity. Finally, the paper demonstrates how English Language can be used to solve the problem of ethnicity and facilitate social cohesion in Nigeria. It also explicates how English Language can be used to stem social disorder and the recurring state of insecurity in Nigeria. The paper recommends among other things, the use of English language in every section of the polity.

\section{The Notion of National Identity}

Identity refers to who we are, what makes us distinct from other people. National connotes that which is shared by a whole nation. National identity therefore refers to the characteristics that make the people of Nigeria distinct from other people.

Culture, traditional values, beliefs and philosophy are purveyors of a people's identity. These are usually expressed in language. Language therefore is an index of a people's identity. Olaoye concurs to this by stating that "Language... is an index of identity which serves as a repository of a people's culture, industry and exploits" (50).

Many scholars believe that national identity and the preservation of local culture can only be achieved through indigenous languages. So, they clamour for the promotion of indigenous languages. Among these scholars are: Adekunle 
1976, Mamman 1985, Olaoye 2010, Agundu 2009 and so on. To them, indigenous languages are symbols of national identity, national pride and national independence. They see indigenous languages as the platform for the expressions of the culture that the invasion of western cultural forms has distorted. For instance, Bewaji avers in Agundu that "language protects the traditions of those that have distinct languages from invasive tendencies, enhances the independence of linguistic groups and is a basis for developing national pride and identity in relevant situations" (103).

In the same vein, Mamman in Adekunle, afraid that the indigenous languages are going into extinction and by extension the nation's identity pleads that:

Nigeria should forget their differences and unite for a common goal, a goal of waging war against English Language, a war of decolonizing our languages before our next generations will one day wakeup to find themselves speaking English as their only language. It would be unfortunate and shameful if the situation got to that stage, for the generation to come will have no cultural heritage (linguistically)to hand over to their own children except the foreign one. (p. 60).

Here, the preservation of indigenous languages seems imperative to the preservation of our national identity. Hence, the call to wage war against English Language which the author designates 'foreign' and claims that it has swallowed up Nigeria's indigenous languages. Again, Olaoye quoting Solanke states that "the most effective engine of a people's culture is their mother tongue. Indigenous languages are treasures of our culture and self identity; in other words, it is the indicator of history and self identification" (p. 50). Here, the author sees self identity and by extension national identity 
as being embedded in the mother tongue. In other words our core traditional values such as honesty, transparency, respect for institutions and constituted authorities and the sanctity of human person and life, that mark our identity, are encapsulated in our indigenous languages (emphasis added) (Olaoye: 56).

From the foregoing, the notion of national identity hinges on the promotion of indigenous languages. For some people, it means the affirmation of independence and waging war against English which they regard as a language of imperialism; and resuscitating the indigenous languages to replace it.

To others, national identity means preserving and showcasing our culture, Philosophy and traditional values via the indigenous languages, not only for our generations to come but also for the entire world. Yet to others, it means stamping our presence in the globe by developing the indigenous languages, in such a way that they can be used in technological and scientific research.

The clamour for the promotion of indigenous languages is motivated by the need to have a sense of belonging, the desire for solidarity and group identity. It is believed that this would help promote national unity and develop a single national consciousness. The reverse however, seems to be the case. This may not be realized due to the ethno-linguistic configuration of Nigeria and its attendant problems, which the next section examines.

\section{The Ethno-Linguistic Configuration of Nigeria}

According to Bamgbose, there are over 400 indigenous languages spoken in Nigeria and not less than 250 ethnic 
groups. Ethnic group is defined by Onwuejeogwu as "a section of population, which is by virtue of sharing a common cultural characteristics separate them from others within the population" (p. 4).

Nationality is a Russian terminology meaning units of nations within the nation state. The ethnic groups in Nigeria fall into this category. They can best be described as units of nations within the nation state. Onwuejeogwu concurs to this by saying that "each ethnic group is a potential nation" (p. 5).

The concept of nationalism Akindele and Adegbite pointed out refers to the feeling of belonging to a nationality. Members of a nationality have solidarity because they share common sociocultural and linguistic habits. Nationality in this sense coincides with ethnic group boundaries in Nigeria. The major ethnic groups are Hausa, Igbo and Yoruba. The minor ones include Edo, Ijaw, Tiv, Kanuri, Nupe, Igala, Jukun, and Idoma; just to mention a few. These ethnic groups are very distinct from one another. Each has its own language, religion and culture. They never considered themselves as descents from the same ancestry. Nothing really binded them together except belonging to the same geo-political entity called Nigeria. Hence, there is no feeling of national unity amongst them. In collaboration to the above statement, Agbedo states that "the exigency of the colonial situation took no cognizance of the salient consensual features that constitute a national character before lumping the pre-colonial disparate nations into one federation" (p. 149).

It is therefore a complex problem trying to form a nation out of 'peoples' of diverse ethnic nationalities, with equally different languages, cultural identities and religious precepts. Hence, 
Agbedo further avers that "the idea of a Nigerian nation is a ridiculous colonial contrivance that can hardly stand the litmus test of nationhood" (p. 149).

So, when we talk about national identity, the strong poser is, which national identity are we pursuing in reality? Is it that of the ethnic nationalities or that of the Nigeria nation state? The bitter truth must be told. What obtain in Nigeria are ethnic attachment, ethnic loyalty and solidarity that over-ride collective national interests.

The major ethnic groups form the major power blocks politically. There is unhealthy rivalry and stiff competition for wealth and power among them. Their leaders engage in inconceivably dastardly acts just to get into power. Once they get there, they control and redistribute the national wealth and resources just to favour their ethnic groups and political affiliations. They do this to the detriment of national interest and national unity. Thus, ethnicity is a strong factor for political mobilization and allocation of national resources. This is a major cause of conflict in Nigeria.

Inter-twined with ethnicity is the language problem. As mentioned earlier, over 400 languages exist in Nigeria. One major issue in a multi-lingual society is the sentimentality attached to the languages by members of the linguistic groups that own them. It is such that any form of act, suggestion or indication that endangers the existence and value of their language is regarded as a threat to their corporate existence. Hence no linguistic group wants to be relegated to the background. Even when the three major languages Hausa, Igbo and Yoruba have been upgraded to some kind of national status, none has been accorded the honour of becoming the 
'one' national language, because such a move would meet with serious and damaging opposition. Thus, Akindele and Adegbite opine that "one of the greatest concerns of the nation is that of language choice - the choice of a national language" (p. 170).

Here, another poser raises its head. When we clamour for the promotion of indigenous languages as a platform for preserving our 'national identity'; the great question is which indigenous language should we promote above the others? As it stands, the minority linguistic groups are not even happy with the elevation of the three major ones. Nigerians as a whole are not ready to accept one indigenous language over 399 others as a national language. According to Enahoro, as cited in Njoku:

All the languages of Nigeria have equal validity, or if you please equal lack of validity, before the law and under the constitution. No linguistic group has the right, moral or constitutional right to impose his (sic) language on any other linguistic group in the country. (p. 621).

Nigeria has suffered a lot of social upheavals due to the ethnolinguistic situation. The section that follows examines some of these problems and the need for social cohesion.

\section{Social Cohesion or National Identity}

Social cohesion refers to the peaceful co-existence of members of a society that is, a people. In other words, it refers to a society that is united. To cohere means "to bring different parts having logical connection so that together they make a whole" (Webster: 190). For the purpose of this paper, social cohesion will be defined as the state of achieving national integration and unity. In other words, the state of achieving 
peaceful co-existence, solidarity in action and purpose amongst the hundreds of ethnic nationalities that makes up the Nigerian polity.

A recourse to history shows that Nigeria has had many cases of social upheavals that have threatened the very existence of the Nigerian nation. Earliest of these conflicts are the circumstances that led to the Nigerian civil war. The Igbo who lived in the North were massacred by northerners in retaliation to the killing of Northern political and military leaders, in a bloody coup staged by Major Kaduna Nzeogwu. This resulted in a full scale civil war that lasted for 3 years. The Igbo had to flee back to their traditional homeland to declare a state of Biafra.

Many instances of ethnic and communal violence abound but only a few will be recounted here. In October 2000, there were clashes between the Hausas and the OPC (a militia group from the west), that led to the death of a nearly hundred people in Lagos (Buhaya, online news). The Ijaw militia movement for the emancipation of the Niger Delta (MEND) and the atrocities they perpetrated at the Niger-Delta region is another example. They demanded for more political franchise. To press home their demand, they resorted to kidnapping the expatriates working in the oil companies and vandalizing the oil pipe lines. The situation has just been calmed by the amnesty granted the militants recently.

The Jos 2010 ethno-religious crises left bitter memories in the lives of the people. Again, the riots and senseless killings that took place in Bornu Kaduna, Bauchi states etc, following the announcement of Goodluck Ebele Jonathan as the winner of the presidential election held on the $16^{\text {th }}$ of April 2011, leaves 
much to be desired. The Northerners took the result of a national election as an ethnic affair and vented their anger on the non-indigene living among them.

Presently, members of the Boko Haram, a fundamental Islamic sect in the North have made a mess of the Nigerian security network. They have through suicide bombing destroyed lives and properties that cannot be quantified. Quoting Senator Sola Adeyeye of Osun State, in his contribution to the debate on Boko Haram activities in Nigeria, he states "Nigeria is hanging on a precipice and the political leadership must at this point rise up to terminate this orgy of violence or the political class will be terminated by it" (. p. 2)

This observation is correct. The dimension this suicide bombing has taken confirms that terrorism is here in Nigeria. This situation places the lives and values of the Nigerian people in serious jeopardy. This dangerous tide has to be stemmed if Nigeria would continue to stay as a single polity.

Some of the causes of social upheavals in Nigeria are: Lopsided power sharing formular, discriminatory access to public service and political appointment, ethnic minorities' phobia for marginalization by large ethnic blocks. (Agbedo: 155)

All these are rooted in ethnicity and the major cause of ethnicity is sentimental attachment to the languages and cultures that bind the members of the different ethnic groups together. The sentimental feelings of loyalty that make their leaders embark on anything to protect their ethnic group to the detriment of national interests. 
Suffice it to say then that the root cause of all these social evils is language. Many scholars confirm that language is central in generating inter-ethnic crises in Nigeria for instance; Olagoke has this to say "when a country speaks with 150 or more different voices, mutual understanding becomes extremely difficult; this has been the major cause of bitterness and suspicion among the different linguistic groups in the country" (p. 19).

The diversity of languages makes communication difficult. It is through communication that collaboration and cooperation occur. In a multi-lingual situation, it is easy to misinterpret or misunderstand what the other has said. Any misunderstanding could generate counter actions and reactions in forms other than language. This is why when there is gap in communication, strained relationships and conflicts occur, which usually degenerate into violence and break-down of law and order.

It is obvious that what Nigeria needs is social integration and national unity English Language bridges the gap in communication amongst the different ethno-linguistic groups. Since no indigenous language is acceptable enough to play the role of the 'one national language', English Language remains the only language that can bring social cohesion and relative peace in Nigeria. The pursuit of national identity via the promotion of any of the indigenous languages would only escalate the crises on ground. This paper therefore suggests the use of English Language in every sector of the polity. The peaceful co-existence which English Language offers should not be sacrificed in our quest for National Identity. 
The section that follows, demonstrates how English Language can be used to solve the problems of ethnicity, social disorder and the recurring state of insecurity in Nigeria.

\section{Advocacy for English Language}

Jowith rightly avers that "at the present time, no single Nigerian language is, or ever will be, sufficiently acceptable to Nigerians to justify its designation as the 'one' national language" (51). Nigerians perceive language as a mark of ethnicity. Hence the elevation of any language connotes the elevation of the corresponding ethnic group. To them, this is highly unacceptable. This situation has paved way for English language to thrive in Nigeria despite the criticisms leveled against it.

Other factors that favour the use of English language in Nigeria are: size, acceptability and the functions it performs. Size, refers to the number of people that speak English and the geographical area it covers. Studies have confirmed that varieties of Nigerian English have emerged and these are spoken by quite a large number of people ranging from, the educated Nigerian to the illiterate cab driver on the street. This paper is not concerned with the varieties, but the point has to be made to confirm that quite a large size of the populace speak English. Again, Elugbe points out in Jowitt that "English is taught nationwide and so has the whole country as its geographic constituency" (37). This is a very big advantage because where majority of Nigerians speak English, they would be part of the decision making process and everybody would have a sense of belonging.

Acceptability refers to the degree to which a language is acceptable to the members of the society where it is used. A few empirical studies on the acceptability of various languages used in Nigeria have been carried out. An instance is the one 
done by Ofuokwu at Ahmadu Bello University, Zaria in 1990. Students from various states completed a questionnaire that touched on issues such as: (a) the importance of mother tongue for expressing 'mother culture', (b) the relevance of a common language to the achievement of greater national unity and, (c) the choice of a national language. From the results of the study, Ofuokwu cited in Jowitt made this observation regarding the choice of national language, it did not matter who made the choice: English Language was preferred to the Nigerian Languages because this is a language that it is not tied to any particular group (44).

The preference for English Language according to Jowitt is because in the ethno-political context, it is considered neutral. This shows that English is widely accepted by Nigerians because it has no ethnic affiliations. It does not engender any ethnic hostility; rather, it ensures peaceful co-existence among the different ethno-linguistic groups that make up the nation.

More so, English Language has bequeathed so many legacies to Nigeria that cannot be easily wished away. It is a vehicle for social interaction and business transactions amongst the people of Nigeria. It avails people from different ethno-linguistic groups the opportunity to interact with one another without suspicion. It is the language of political administration, the language of education, the language of international relations and the mass media. English Language also provides Nigerians a window to the global world.

According to Nwigwe, the mass media is an essential and indispensable agency in government and the general society. It is a powerful tool for mobilizing people. Information is power and the language for disseminating information is very 
important. In Nigeria, the major language of the mass media is English. The choice of English as the language of the mass media cannot be faulted. It defies ethnic boundaries and cuts across every linguistic group. So, information is easily disseminated to Nigerians. If the citizens are well informed on the activities of the government, the result would be good followership. There would not be so much suspicion and antagonism. Frequent eruptions of violence would certainly abate.

Considering the state of insecurity in the country, and the near disintegration of the Nigerian nation due to frequent violent social disorder; this paper strongly submits that English Language is a potent factor for achieving social cohesion and the much needed national integration and unity.

Essentially, English Language plays a unifying role in a multilingual and multi-ethnic nation as Nigeria. Many writers affirm this such as: Nwachukwu, Afolayan, Ogu etc. For instance, Nwachukwu avers that the removal of English from our education system and polity (and replacing it with an indigenous language) will amount to cutting the string that holds the country together.Again, Ogu cited in Njoku and Izuagba reaffirms this by saying:

The English Language brought under one umbrella people from diverse languages and ethnic groups. Here was a language that was not based on one ethnic group of one geographical area. People found in it the unobtainable linguistic unity that they so much craved for. The non-ethnic nature provided them with a means for peaceful co-existence and communication. (p. 5).

Similarly, in discussing the usefulness of English as a unifying force in Nigeria, Afolayan in Nwigwe states that: "It is 
unrealistic for anybody in Nigeria to think that national unity can be forged in the country without recourse to the utilization of the English Language; furthermore, the fact that it is now functioning as the language of nationalism cannot be denied" (p. 79).

From every indication, it is clear that English Language has come to stay and is indispensable in the Nigerian polity. In the views of Onuigbo, "there is no better linguistic candidate for national integration, unity and identity than the English Language. No Nigerian Language can be considered as a useful tool for this Herculean task" (p. 46).

Again, the late literary giant, Chinua Achebe, votes for the indispensability of English in our scheme of things. He unequivocally maintains in Onuigbo and Eyisi that:

We can believe in the value of English for the survival of the Nigerian nation without feeling like deserters... we can use energies constructively in the important task of expanding the frontiers of English to cover the whole area of our Nigerian consciousness. (p. 50).

This means that English Language can be expanded to accommodate our Nigerianess. In this light, English Language has undergone some indigenization processes, to the extent that a distinct variety called Nigerian English is recognized. In the words of Jowith "this has rendered English uniquely serviceable for the task of generating a healthy national consciousness, social development and national unity (emphasis added) (54).

All that our scholars need to do is to rise to the task and work on this distinct variety of English recognized as Nigerian English. Standardize certain features and lexical choices across 
the country; make it available in form of textbooks to be taught in Nigerian schools. This way, Nigerians would not feel it is alien, since it can be used to express the Nigerian experience and can also encapsulate our cultural values.

\section{Conclusion}

Indigenous Languages are no doubt the indices of a people's identity. They encapsulate our core traditional values that identify us and make us distinct from other people. The pursuit for national identity via the promotion of indigenous languages is not a bad idea. But the nature of Nigeria would make the realization of this lofty ideal a mirage.

Nigeria as a multi-lingual and multi-ethnic nation is already beset with so much social crises already. The concern of this paper is how these problems can be solved using a linguistic option.

The pursuit of national identity through the promotion of indigenous languages would only fan the ambers of crises in Nigeria. Some mind bogging questions come up over the issue of national identity. Since Nigeria is made up of different ethnic nationalities who pursue the interest of their various ethnic groups at the detriment of national concerns; the pertinent question is: which national identity do we mean? Is it that of the ethnic nationalities or that of the Nigeria-nation state? Even when we clamour for the promotion of indigenous languages, another mind bogging question comes up: which indigenous Language do we promote above the others?

Since there are no ready answers to these questions, it is obvious that what Nigeria needs more is social cohesion, that is - national integration and peace. The position of this paper 
is: let the spirit of nationalism be inculcated into the people first. Again, let there be development of 'a single national consciousness amongst the citizenry. Then, we can talk about 'national identity' captured in a 'national language'.

For the development of this single national consciousness, Nigeria needs a linguistic network that will facilitate social cohesion, national integration and unity. This paper therefore recommends the use of English Language in every section of the polity. English is the string that holds Nigeria together. It is the language of wider communication in the face of multilingualism. It has no ethnic affiliation in Nigeria; moreover it occupies the prestigious status of a second language.

English Language is meant to carry everybody along as well as clear misconceptions about others. What government should do is to ensure unfettered flow of information from the presidency down to the masses. If people are informed, they have a sense of belonging and the feeling that they are part of the decision making process. Then everybody is happy, there won't be any uprisings, militancy or ethnic clashes. There would be peaceful co-existence and the foundation for developing 'a single national consciousness' would be laid, which would in turn result in the much needed national unity.

\section{Works Cited}

Adekunle, Mobolaji. "English in Nigeria: Attitudes, Policy and Communicative Realities". In Bamgbose et al. (Ed.) New Englishes A West African Perspective. Ibadan, Nigeria: The British Council. 1995. 57-86.

Adepegba, A. "Manhunt for Boko Haram Bombers Grounds Abuja". The Punch, July 5, 2011. p. 2. 
National Identity Versus Social Cohesion: An advocacy for English Language Juliana Chinwe, Njoku \& Chika Queen Udeh

Agbedo, Chris. Problems of Multilingual Nations: The Nigerian Perspective. Enugu-Nigeria: Fidgina Global books. 2007.

Agundu, Oliver Tersoo, "Rethinking the Language Question in African Philosophy". In Nyitse, Mbaiver L. (Ed). Makurdi Journal of Language and Literature. Vol. 1. No. 1. Makurdi, Benue State: Bookwork Publishers. 2009. 101-112.

Akindele, Femi and Adegbite, Wale. The Sociology and Politics of English in Nigeria. Ibadan: OAU press. 1999.

Bamgbose, Ayo Speaking Tongues: Implication of Multilinguistism for language policy in Nigeria". National Merit Award Lectures. Vol. 3.

Buhaya, Noah "Ethnicity in Nigeria: Background Report". The PBS Online News Hour www.pbs.prg//ethnichtml

Jowitt, David. "Nigeria's National Language Question: Choices and Constraints". In. Bamgbose et al (Eds) New Englishes A West African Perspective. Ibadan, Nigeria: The British Council. 1995. 34-56.

Njoku, Theresa and Izuagba, Angela. New Approaches to English Language and Literature Teaching. Owerri: Versatile Publishers 2004.

Njoku, Juliana. "The Role of English Language in Achieving Sustainable Democracy in an Ethnically based society". 
In Chiegboka et al (Eds). The Humanities \& Sustainable Development. A Journal of the Faculty of Arts, N.A.U., Awka, Anambra. 2011. 617-622

Nwigwe, Ngozi. "Language Classification in Teaching and Learning". In Nwachukwu et al Introduction to Language and Applied Linguistics Owerri: Cel-Bez co. Publishers. 2007. 67-92.

Olagoke, David O. "The Mother-Tongue and ESL in Nigerian Education". In Ubahakwe, Ebo (ed) The Teaching of English Studies: Readings for Colleges and Universities. Ibadan, Nigeria: Ibadan University Press. 1979. 15-26.

Olaoye, Anthony A. "Indigenous Languages and National Development" In Ayakoroma, Barclays \& Obafemi, Olu (eds) Perspectives on Cultural Administration in Nigeria. 2010. 50-63.

Onuigbo Sam and Eyisi Joy, English Language in Nigeria: Issues and Developments. Calabar: Paclen Publishers. 2009.

Onwuejeogwu, Angulu M. The Multi-Ethnic Nationalities of Nigeria and the Problems of Governance. Institute of African studies, University of Ibadan Project. 1972. 